\section{Follow-up of glomerular hyperfiltration in normoalbuminuric Type 1 (insulin-dependent) diabetic patients}

\section{Dear Sir,}

In a recent paper Jones et al. [1] report after a 5-year prospective study that the glomerular filtration rate (GFR) of hyperfiltering Type 1 (insulin-dependent) diabetic patients fell faster than that of normofiltering patients. We would like to report the data of our prospective case-control study of 21 Type 1 (insulin-dependent) diabetic patients (12 males; 9 females) with a normal urinary albumin excretion rate $\left(\mathrm{AER}<30 \mu \mathrm{g} \cdot \mathrm{min}^{-1}\right)$ and without arterial hypertension $(<160 / 95 \mathrm{~mm} \mathrm{Hg})$.

The patients were divided into two groups according to their GFR. Hyperfiltering patients had a GFR above the normal range of our laboratory $\left(96-134 \mathrm{ml} \cdot \mathrm{min}^{-1} \cdot 1.73 \mathrm{~m}^{-2}\right)$. The GFR of hyperfiltering patients $(n=14)$ was $155.7 \pm 18.4 \mathrm{ml} \cdot \mathrm{min}^{-1} \cdot 1.73 \mathrm{~m}^{-2}$ and in the normofiltering group $(n=7)$ was $106.5 \pm 16.9 \mathrm{ml} \cdot \mathrm{min}^{-1}$. $1.73 \mathrm{~m}^{-1}$. The base-line clinical characteristics of the hyperfiltering were not different from the normofiltering group: age $30.2 \pm 4.9$ vs $29.0 \pm 6.5$ years, duration of diabetes $5.0 \pm 3.1$ vs $7.1 \pm 7.6$ years, $\mathrm{HbA}_{\mathrm{lc}} 10.1 \pm 2.2$ vs $10.7 \pm 1.9 \%, 24$ h urinary urea $25.4 \pm 12.3$ vs $17.0 \pm 4.9 \mathrm{~g}$, AER $5.4 \pm 5.9$ vs $6.7 \pm 7.9 \mu \mathrm{g} \cdot \mathrm{min}^{-1}$ and mean blood pressure $91.7 \pm 10.5$ vs $86.8 \pm 7.7 \mathrm{~mm} \mathrm{Hg}(p>0.05)$. Informed consent was obtained from each patient. Arterial blood pressure was measured with a standard mercury sphygmomanometer to the nearest $2 \mathrm{~mm} \mathrm{Hg}$ with the patients in the seated position after $5 \mathrm{~min}$ rest. The GFR was measured by the single injection 51-CrEDTA technique after an overnight fast. AER (radioimmunoassay-DPC) and urea were measured in $24-h$ urine collections. These measurements were performed about every 3 to 12 months. The number of measurements in each patient ( $3.8 \pm 1.8$ vs $3.4 \pm 1.4)$ and the followup period $(42.0 \pm 8.9$ vs $39.7 \pm 15.2$ months $)$ were not different between the two groups $(p>0.05)$. The change of GFR over time was analysed by a regression line determined for each patient and the mean slopes were then calculated. The results were also analysed by calculating the difference between the initial and the most recent values and dividing by time. Student's unpaired $t$-test was used to compare the results between hyperfiltering and normofiltering groups and one sample $t$-test to assess whether a specific variable changed during the observation period (different from zero). Twotailed tests were used. The results are given as means $\pm \mathrm{SD}$. The level of significance was set at $5 \%$.

The GFR of hyperfiltering patients decreased by a rate of $-0.47 \pm 0.49 \mathrm{ml} \cdot \mathrm{min}^{-1} \cdot \mathrm{month}^{-1}$ (linear regression analysis, $p<0.05$ ) or $-0.52 \pm 0.57 \mathrm{ml} \cdot \mathrm{min}^{-1} \cdot$ month $^{-1}$ (difference between initial and final values, $p<0.05$ ). On the other hand the GFR did not change in the normofiltering group: $0.18 \pm 0.54 \mathrm{ml} \cdot \mathrm{min}^{-1} \cdot \mathrm{month}^{-1}$ (linear regression analysis, $p>0.05$ ) or $0.17 \pm 0.54 \mathrm{ml} \cdot \mathrm{min}^{-1}$. month $^{-1}$ (difference between initial and final values, $p>0.05$ ). The rate of decline of GFR of the two groups (assessed by both methods) was significantly different $(p=0.01)$. The $\mathrm{HbA}_{1 \mathrm{c}}$ and mean blood pressure did not change in the hyperfiltering group $(p>0.05)$ but decreased in the normofiltering group $(p<0.05)$ although these changes were not different when compared to the hyperfiltering group. Urinary urea did not change in either group. No patient presented AER above $30 \mu \mathrm{g} \cdot \mathrm{min}^{-1}$ at the end of the follow-up period.

The rate of decline of GFR described in our hyperfiltering patients is very similar to that reported by Jones et al. [1]. This decrease of GFR cannot be explained by improved metabolic control because, contrary to Jones et al. [1], we did not observe any change in $\mathrm{HbA}_{\mathrm{lc}}$ levels. Dietary protein has a profound effect on kidney function [2] and we reported previously that even a short period of lowprotein diet can reduce GFR [3]. This aspect was not studied by Jones et al. [1] but in our patients we did not observe any change in the 24-h urinary urea, a reliable index of protein intake. Longer periods of follow-up are needed to establish the meaning of the observed decline of GFR in hyperfiltering patients.

Yours sincerely,

M. J.Azevedo and J.L. Gross

\section{References}

1. Jones SL, Wiseman MJ, Viberti GC (1991) Glomerular hyperfiltration as a risk factor for diabetic nephropathy: Five-year report of a prospective study. Diabetologia 34: 59-60 (Letter)

2. Wiseman MJ, Hunt RE, Goodwin A, Gross JL, Keen H, Viberti GC (1987) Dietary composition and renal function in healthy subjects. Nephron 46:37-42

3. Azevedo MJ, Padilha LM, Gross JL (1990) A short-term low-protein diet reduces glomerular filtration rate in insulin-dependent diabetes mellitus patients. Brazilian J Med Biol Res 23: 647-654

Prof. J.L. Gross

Grupo de Pesquisa e Pós-Graduação

Hospital de Clinicas Porto Alegre

Ramiro Barcelos, 2350

90.210-Porto Alegre, RS

Brazil 